\title{
ASSÉDIO MORAL: UMA ABORDAGEM NA RELAÇÃO DE EMPREGO
}

\author{
Raísa Alexandre de Oliveira ${ }^{1}$ \\ Peterson Batista Pio Machado ${ }^{2}$ \\ Ihgor Jean Rego ${ }^{3}$
}

RESUMO: Este estudo versa sobre o fenômeno do assédio moral praticado no ambiente de trabalho, como evento nocivo à saúde do empregado e à higidez do ambiente laboral. No Brasil, ainda não há uma lei federal que trate do tema, definindo-o e impondo sanções, por exemplo. Existem apenas tentativas singelas e coadjuvantes de coibir a prática. Sendo assim, o tema trata da questão se qualquer pessoa poderá ser potencialmente uma vítima da violência perversa, o que traz à tona a importância do tema. Assim, este trabalho pretende apresentar uma visão geral sobre o assédio moral no ambiente de trabalho, suas características e consequências. Para tanto, apresenta-se inicialmente o conceito do instituto, através da visão doutrinária, seus elementos, suas diversas nomenclaturas e o posicionamento jurisprudencial. Em seguida, estudam-se os sujeitos da violência perversa, suas espécies, e faz-se uma diferenciação entre o fenômeno em estudo e outros institutos. Por fim, serão abordadas as fases, os danos, a prova, prescrição e a forma de tratamento do assédio moral no ambiente de trabalho na legislação brasileira e no direito comparado. Este estudo consistiu-se em pesquisa aplicada, de caráter cientifico dedutivo, e com o método auxiliar comparativo, bem como o explicativo e, por se tratar de um tema polêmico e que permanece atual, trouxe em seu contexto fundamentos jurídicos para mostrar ao leitor de forma clara e coesa o entendimento majoritário de especialistas relacionado ao tema.

Palavras-chave: Assédio moral. Ambiente de trabalho. Mobbing. Dignidade da pessoa humana. Relação de emprego.

ABSTRACT: This paper studies the phenomenon of moral harassment practiced in the workplace, such as noxious event to employee health and the health of the work environment. In Brazil, there is still no federal law dealing with the issue, by defining it and enforcing the sanctions for the author, for example. There are only unpretentious attempts to curb the practice. Anyone is a potential mobbing victim, which brings to light the importance of the theme. Thus, this paper intends to present an overview of

\footnotetext{
I Graduanda em Direito pela Faculdade São Lucas - Porto Velho-RO. Endereço eletrônico: raisaalexandre97@gmail.com

2 Graduando em Direito pela Faculdade São Lucas - Porto Velho-RO. Endereço eletrônico: peterson.pio@bol.com.br

${ }^{3}$ Orientador do presente artigo e professor do Centro de Ensino São Lucas - Porto Velho-RO.
} 
psychological terror at workplace, its characteristics and consequences. To do so, the article presents the phenomenon's concept, through doctrinal view; its elements; its various nomenclatures and the jurisprudential position. Then, the subjects of the emotional abuse will be studied, as their kind, and a distinction between the phenomenon under study and other similar figures. Finally, it will discuss the phases, damages, evidence, prescription, and how Brazilian and international law treat the problem.

Keywords: Moral harassment. Work environment. Mobbing. Dignity of human being. Employment relationship.

\section{INTRODUÇÃO}

Um antigo problema das relações trabalhistas ganhou mais destaque nas últimas décadas: o assédio moral. As pressões por maior produtividade e o distanciamento entre empregados e empregadores culminaram na desumanização do ambiente de trabalho. Desdeque se construiu uma hierarquia entre homens e seus semelhantes, o assédio esteve presente, manifestando-se em suas mais variadas perspectivas.

Os estudos sobre assédio moral iniciaram-se no campo da biologia, quando o etologista Konrad Lorenz, na década de 1960, analisou o comportamento de animais de pequeno porte que se uniam em grupo para atacar outro animal de maior porte, quando este invadia seu território. A esse fenômeno deu o nome de mobbing. Comportamento semelhante foi observado, ainda na década de 6o, em um estudo realizado com crianças, dentro de um ambiente escolar, por Peter-Paul Heinemann.

As análises sobre agressões morais no ambiente de trabalho, no entanto, só se desenvolveram na década de 1980, com os trabalhos do psicólogo alemão Heinz Leymann, e, mais tarde, no ano de 1998, com a obra "Assédio Moral: A Violência Perversa no Cotidiano”, da psicanalista francesa Marie-France Hirigoyen, a qual abordou o tema nas suas mais variadas perspectivas, inclusive nas relações de trabalho.

A partir daí, o tema em estudo passou a ser conhecida por diversas nomenclaturas, como mobbing ou bullying, violência perversa ou psicológica no ambiente de trabalho, dentre outras.

Em linhas gerais, costuma-se definir o fenômeno em estudo como uma conduta de natureza eminentemente psicológica, que atinge diretamente a dignidade do agredido, de forma repetitiva, cujo objetivo principal é excluir o assediado do ambiente de trabalho. 
Segundo Renato Muçouçah, constatou-se que, nos últimos anos, houve um aumento da observância a esse instituto e seus efeitos perversos, os quais compreendem: baixa autoestima, doenças físicas, enfermidades psíquicas e até mesmo a morte. Esse problema tem sido discutido com maior intensidade por órgãos internacionais, pelas empresas, sindicatos, e, também, pelo Direito.

Por ser uma conduta, o assédio moral possui sujeito ativo, sujeito passivo e requisitos para que seja caracterizado.

O sujeito ativo pratica a conduta e costuma ser superior hierárquico ou empregador do assediado, porém, subordinados ou colegas de trabalho também podem agir como autores da violência. De onde parte o assédio moral é o que enseja sua classificação em espécies, a qual será estudada em capítulo próprio. $O$ sujeito passivo é quem sofre a conduta e pode figurar emqualquer polo da relação trabalhista.

Quanto aos requisitos, de uma forma geral, tem-se uma conduta intencional praticada contra a dignidade e integridade psíquica de alguém, prejudicando tanto a vítima, quanto o ambiente de trabalho. A doutrina ainda cita a necessidade de repetição da conduta. Osrequisitos ou elementos caracterizadores serão estudados também em capítulo próprio.

Além do fato de se tratar de um tema bastante contemporâneo, a importância do estudodo assédio moral no ambiente de trabalho reside em diversos fatores.

Nesse diapasão, debate-se a problemática: Se qualquer pessoa envolvida em uma relação trabalhista é uma vítima em potencial desse fenômeno e se suas consequências têm efeitos diretos na vida do indivíduo?

O estudo desse tema tem características interdisciplinares, passando pelo trabalho e pelo Direito Material e Processual do Trabalho, pelo Direito Constitucional e Civil quando se trata de violação aos direitos individuais, pela Psicologia, e pela Medicina do Trabalho.

Apesar de ser um problema antigo, o tema é muito atual, haja vista ter sido agravado pela forma como as recentes relações trabalhistas são tratadas, estando intimamente ligado ao modo de produção capitalista da sociedade moderna.

O tema não é enfrentado pela legislação brasileira, deixando as vítimas à deriva no 
assunto, dependendo de uma incerta decisão judicial que não tem como base uma lei específica que trate da matéria, aumentando a insegurança jurídica.

Vale ressaltar, ainda, o fato de haver certa dificuldade em se delimitar o fenômeno em estudo, separando-o de conflitos normais - próprios do ambiente de trabalho, de outras modalidades de assédio, ou mesmo de conduta jocosa do suposto agressor e que a vítima não entende.

Assim, o objetivo deste estudo é apresentar uma visão geral sobre o fenômeno do assédio moral no ambiente de trabalho, caracterizá-lo, apresentando seus elementos e espécies, além de diferenciá-lo de fenômenos semelhantes. Para tanto, o presente artigo foi dividida em 3 (três) Capítulos, de forma que: O tópico I abordará o conceito, os elementos constitutivos, a caracterização do assédio moral no ambiente de trabalho e suas diversas nomenclaturas, deixando para o tópico II os sujeitos, as espécies e uma diferenciação, comparando-o com institutos que muito se lhe assemelham, tais como o assédio sexual e o poder diretivo do chefe. No tópico III, serão abordadas as fases nas quais se desenvolve o instituto, os danos que causa a prova, prescrição e a forma de tratamento na legislação nacional e no direito comparado.

\section{CONCEITO, ELEMENTOS, NOMECLATURA E COMPETÊNCIA}

\section{I Conceito}

A origem do termo "assédio moral” está relacionada aos efeitos que causa na esfera psíquica do agredido.

O termo "assédio" designa uma conduta caracterizada pela insistência inoportuna, visando a quebrar a força, a vontade do assediado. É uma insistência impertinente de alguém em relação à outra pessoa.

Já a expressão "moral" se refere tanto ao conjunto de regras de conduta de uma sociedade, seu manual de boas práticas, quanto ao lado psicológico da vítima, à alma do agredido, os quais sofrem violações a partir da conduta do agente. (NAVARRO, 2019).

Devido ao fato de não haver legislação que nomeie e defina o instituto de forma precisa, recaiu sobre a doutrina tal tarefa. Não há, porém, unanimidade entre os doutrinadores no que tange ao conceito, haja vista ser um fenômeno dotado de muitas 
peculiaridades. Pode- se, entretanto, encontrar alguns elementos comuns, os quais formama base para a caracterização do assédio moral.

Para Marie-France Hirigoyen, o instituto em questão é:

toda e qualquer conduta abusiva (gesto, palavra, comportamento, atitude [...] que atente, por sua repetição ou sistematização, contra a dignidade ou a integridade psíquica ou física de uma pessoa, ameaçando seu emprego ou degradando o climadetrabalho. (HIRIGOYEN, 2017, p. 17).

Por sua vez, Sônia Mascaro Nascimento conceitua o fenômeno como:

uma conduta abusiva, de natureza psicológica, que atenta contra a dignidade psíquica, de forma repetitiva e prolongada, e que expõe o trabalhador a situações humilhantes e constrangedoras, capazes de causar ofensas à personalidade, à dignidade ou à integridade psíquica, e que tenha por efeito excluir a posição do empregado no emprego ou deteriorar o ambiente de trabalho, durante a jornada de trabalho e no exercício de suas funções. (NASCIMENTO, 2017, p. 922 - 930).

Então, em linhas gerais e tomando por base os conceitos acima, podemos definir assédio moral no ambiente de trabalho como conduta de natureza psicológica, praticada no ambiente de trabalho ou no exercício das funções, e que indica um comportamento repetitivoe injusto, cujo objetivo é constranger o assediado, causando ofensa direitamente à dignidade, à personalidade, à integridade psíquica do ofendido e, de forma indireta, a sua integridade física.

Cada um dos elementos acima tem sua importância na caracterização do fenômeno emestudo, de forma que serão estudados separadamente a seguir.

\subsection{Dos elementos}

A partir do conceito podemos extrair o conjunto de fatores que compõe e caracterizao assédio moral:

\subsubsection{Conduta de natureza psicológica}

A ação praticada pelo agressor visa a atingir a dignidade da vítima, a macular a imagem do agredido perante si mesmo e perante outrem.

Prejudica-se a saúde mental do assediado por meio de humilhações, exposições ao ridículo, isolamento, boicote, delegação de funções que não condizem com a sua qualificação do profissional. (MARTINS, 2017). 
Ressaltamos o fato de a ação não ter um viés físico entre agressor e agredido. A conduta se restringe ao campo das palavras e das atitudes. Se, no entanto, a agressão, antes psicológica, começa a apresentar uma vertente física, pode ficar caracterizado ilícito penal. Este, por sua vez, varia conforme o caso, podendo estender-se de uma lesão corporal leve ao crime de estupro/assédio sexual, por exemplo.

\subsubsection{A prática da conduta deve se dar no ambiente de trabalho ou quando o empregadoesteja no exercício de suas funções}

O assédio moral se manifesta nas mais variadas relações humanas, por exemplo, em um contexto familiar ou conjugal. Porém, devido aos motivos já explicados alhures, só contemplaremos a violência perversa que acontece no ambiente de trabalho, ocorrendo também se o agredido encontrar-se no exercício de suas funções, fora do ambiente laboral, já que a ele ainda encontra-se vinculado.

\subsubsection{Repetição dos atos de assédio}

A doutrina costuma ser unanime em relação à necessidade de repetição dos atos de violência psicológica para que reste caracterizado o assédio moral.

Um único ato isolado não configuraria a violência psicológica. Segundo Leymann (2012), a agressão deve ocorrer ao menos uma vez por semana, por um período mínimo de 6 (seis) meses.

Porém, grande parte da doutrina, a exemplo de Sérgio Pinto Martins (2017) a respeito do elemento "repetição", se posiciona no sentido de não haver um prazo para configurar o assédio moral, mas apenas o fato de a conduta violenta ser reiterada tempo suficiente para quecause um dano.

Cada indivíduo tem em si uma resistência emocional, uma estrutura cuja quebra pode se dar mais facilmente em uns e maneira mais difícil em outros.

Ao estabelecermos um prazo para configurar o assédio moral, corremos o risco de tratarmos condutas iguais de formas diferentes, apenas porque uma se prolongou um pouco mais que a outra.

Assim, a princípio, um mero ato isolado não configuraria o assédio psicológico. No entanto, faz-se necessária a avaliação de cada caso isoladamente, devido à estrutura 
emocional particular de cada indivíduo, como também à intensidade da agressão realizada ese esta foi uma conduta única ou uma cominação de tantos outros atos.

\subsubsection{Existência de Dano}

Por mais depreciativa que a ação do agressor seja, se não causar nenhum dano à vítima, não configura o assédio moral. Em verdade, não restará caracterizada conduta alguma no âmbito do direito se o procedimento for infrutífero.

Como consequência da atitude lesiva, deve haver um prejuízo em nível psicológico ao agredido, uma violação aos seus princípios, a sua moral e dignidade.

Essa esfera íntima do indivíduo encontra proteção legal na Constituição Federal, como Fundamento da própria República:

Art. Io A República Federativa do Brasil, formada pela união indissolúvel dos Estados e Municípios e do Distrito Federal, constitui-se em Estado Democrático de Direito e tem como fundamentos:

[...] III - a dignidade da pessoa humana. (BRASIL, 1988).

Dignidade como princípio consiste em um valor individual e intrínseco da pessoa, desaguando na sua autodeterminação consciente e responsável e no respeito a si e a outras pessoas. Ainda, segundo Alexandre de Moraes (MORAES, 2017), esse princípio edifica um mínimo invulnerável de direitos fundamentais, o qual deve ser assegurado por todo ordenamento jurídico.

A conduta do agressor visa a ferir parte desses direitos, através de atos que modificam a forma como o assediado se vê e como é visto pelos demais colegas de trabalho, tornado insustentável a permanência da vítima no emprego.

Também, como consequência do estresse e do trauma causados pelo assédio, pode haver a existência de um dano físico, resultado de doenças.

Esse elemento será aprofundado mais a frente, quando se tratar dos danos causados pela violência perversa praticada no ambiente de trabalho.

\subsubsection{Nexo Causal}

O dano dever ser derivado da conduta intencional do agressor. Se a conduta não for intencional, ou não tiver intensidade para causar lesão a uma pessoa mediana, não haverá 
assédio.

Também, a atitude do agressor deve ser voltada ao dano psíquico, pois, a depender de sua intenção, pode caracterizar outro instituto como o assédio sexual ou o mero poder diretivodo empregador.

Veja-se que há um alto grau de subjetividade envolvido, pois há momentos nos quais asuposta vítima pode estar mais suscetível a ferir-se com comentários de colegas ou de seu chefe, que, por sua vez, não tinham o objetivo de assediá-la. A ansiedade e o estresse vividos em outro momento podem deixar os sentimentos a flor da pele, transformando uma situação cotidiana em algo muito maior.

Quanto a sua natureza jurídica, o assédio moral é enquadrado como ato discriminatório. (MARTINS, 2017).

COMPETÊNCIA

Por ser um conflito oriundo de um contrato de trabalho, o assédio moral atrai a competência da Justiça do Trabalho, nos termos do artigo II4, inciso I, da Constituição da República (in verbis):

Art. II4. Compete à Justiça do Trabalho processar e julgar: (Redação dada pela Emenda Constitucional no 45, de 2004).

I as ações oriundas da relação de trabalho, abrangidos os entes de direito público externo e da administração pública direta e indireta da União, dos Estados, do Distrito Federale dos Municípios; (Incluído pela Emenda Constitucional no ${ }^{4}$, de 2004).

No presente trabalho apenas será estudado o assédio moral proveniente das relações deemprego.

\section{SUJEITOS DO ASSÉDIO MORAL, ESPÉCIES E DIFERENCIAÇÃO}

\subsection{Sujeitos do assédio moral}

Como conduta, o fenômeno em estudo possui tanto quem pratica a ação - chamado de sujeito ativo, agressor, assediador, etc., quanto aquele para o qual a atitude é direcionada - sujeito passivo, agredido, vítima, assediado etc.

O sujeito ativo pode ser um colega da vítima, seu superior ou inferior hierárquico. Segundo Marie-France Hirigoyen (2017), tem como característica a presença de traços narcísicos em sua personalidade (egocentrismo, intolerância, megalomania etc.), assim 
como alta capacidade de manipulação do ambiente e das pessoas ao seu redor.

No entanto, é uma pessoa que não consegue cumprir com todas as suas responsabilidades não reconhecem seus defeitos, não sabe receber críticas, não admira nem apoia os colegas de trabalho. Dessa forma, necessita rebaixar alguém para demonstrar suas qualidades e para elevar a autoestima. Através de suas condutas, utiliza e depois descarta a vítima sem a menor culpa, sempre com o objetivo de denegrir o agredido e o ambiente de trabalho.

Já o sujeito passivo costuma ser alguém altamente capacitado, perfeccionista, esforçado, criativo, competente, com alta produtividade e desempenho, e que cumpre com presteza suas funções. Os assediados apresentam um perfil satisfatório às exigências do mercado e, por isso, são alvos da inveja dos agressores. (HIRIGOYEN, 2017).

É importante notar o fato de o assédio moral só envolver as pessoas ligadas à empresa por meio de vínculo empregatício, pessoas que a ela pertencem.

O cliente, por exemplo, não poderia assediar moralmente empregado da empresa, noâmbito das relações laborais, pelo menos. Inclusive, se a violência perversa partisse de um cliente, a competência para a resolução do conflito deixaria de ser da Justiça do Trabalho.

Seguindo o mesmo raciocínio, a prática da violência perversa restaria desconfigurada se a conduta for voltada para estagiário. Pode haver a caracterização de atos discriminatórios por motivo de cor, religião etc., mas, em tese, não assédio moral.

\subsection{Espécies de assédio moral}

A classificação mais comum depende da posição hierárquica ocupada pelo agente causador da violência perversa, segundo a doutrina Sérgio Pinto Martins consiste em:

a) Assédio Moral Vertical: ocorre quando a relação de assédio sedesenvolve entre pessoas de níveis hierárquicos diferentes - um dos sujeitos ocupa um cargo mais alto, o outro é a ele subordinado.

Se o sujeito ativo for o superior hierárquico, acontece o chamado assédio moral vertical descendente. Já se o empregado ou o conjunto de empregados agredirem seu chefe há o assédio moral vertical ascendente.

b) Assédio Moral Horizontal: acontece quando os sujeitos da violência perversa estão no mesmo patamar hierárquico. Não há subordinação entre quem pratica e quem sofre a ação;

c) Assédio Moral Misto: resta caracterizado se a violência contra o sujeito 
passivo parte tanto do superior, quanto das pessoas que estão no mesmo patamar hierárquico;

No entanto, há diversas outras espécies de violência psicológica no ambientede trabalho, por exemplo, (MARTINS, 2017, p. 28-31):

d) Assédio Moral Individual: praticado contra uma única pessoa específica;

e) Assédio Moral Coletivo: realizado por um grupo contra uma pessoa;

f) Assédio Moral Institucional: quando uma empresa determina que sejam realizados trabalhos os quais implicam em prejuízo à dignidade de seus empregados;

g) Assédio Moral Estratégico: o empregador usa de violência perversa para fazer com que o empregado peça demissão, tendo o escopo de não pagar verbas rescisórias. Assim, livra-se do empregado com o menor custo possível.

h) Assédio moral-repressão: costuma ser violento e direcionado a empregados com grande visibilidade e que se impõem ao chefe. Por exemplo, o representante de pessoas e o dirigente sindical.

i) Assédio moral perverso: a conduta se prolonga no tempo, porém, temo objetivo de fazer a vítima permanecer na empresa, para continuar a ser assediada;

j) Assédio moral discriminatório: é tratamento desigual causado devido à cor, religião, sexo, idade etc.;

k) Assédio moral por delegação: quando o superior hierárquico manda que um empregado pratique assédio contra outra pessoa. (MARTINS, 2017, p. 28-31).

Por meio do estudo das espécies do assédio moral é que se identificam as consequências jurídicas de sua prática. A doutrina tem classificado o assédio moral em vertical descendente, horizontal, vertical descendente e coletivo, considerando a qualidade e quantidade do(s) agente(s) e da(s) vítima(s).

\subsubsection{Assédio Moral x Assédio Sexual}

Feita a definição do que consiste a violência perversa no ambiente de trabalho em outro momento, cabe-nos, agora, analisar o assédio sexual, com o objetivo de estabelecer as diferenças e relações entre os institutos.

A conduta de um indivíduo é influenciada por sistemas normativos de instancias informais, como a religião e o moralismo. $\mathrm{Na}$ esfera sexual, cada indivíduo determina um valor próprio para suas ações e a sociedade, difusamente, valora em escalas distintas.

No entanto, a tutela jurídica da liberdade sexual é indiferente a conceitos morais ou religiosos. Visa apenas a garantir, nesse âmbito, a autodeterminação do individuo, para usá-la da maneira como melhor entender. 
Em atenção aos desejos da sociedade e alinhado com os Direitos Fundamentais do cidadão, o Estado tipificou a conduta descrita como assédio sexual, elevando-a a categoria de crime justamente por atentar contra a autodeterminação sexual da vítima. Tal regramentoencontra-se no art. 216-A, do Código penal Brasileiro, o qual dispõe, in verbis:

Assédio sexual (Incluído pela Lei no 10.224 , de I5 de 200I).

Art. 216-A. Constranger alguém com o intuito de obter vantagem ou favorecimento sexual, prevalecendo-se o agente da sua condição de superior hierárquico ou ascendência inerentes ao exercício de emprego, cargo ou função. (Incluído pela Lei no ${ }^{\circ}$ 10.224, de Is de 200I). (BRASIL, 200I).

Assim, para a subsunção da norma ao fato, faz-se necessário que o sujeito ativo, superior hierárquico ou empregado exercente de cargo de chefia, valha-se abusivamente dos poderes inerentes ao seu cargo, emprego ou função, para constranger alguém a ele subordinado, com o objetivo de obter vantagem ou favorecimento sexual.

O agente usa sua ascendência na cadeia hierárquica para exigir da vítima a prática de conduta de cunho sexual sob algum pretexto, seja a ameaça de perda do emprego ou rebaixamento na escala de funções, seja uma promoção, por exemplo. Verificamos, dessa forma, que resta tipificada uma modalidade de assédio sexual por chantagem - quid pro quo (isto por aquilo) (MUÇOUÇAH, 2017).

Reside neste ponto uma das diferenças entre a violência perversa e o assédio sexual. Enquanto o segundo apenas pode ser praticado por superior hierárquico ou empregado que lhefaça às vezes, mesmo temporariamente, o assédio psicológico pode ser praticado tanto por superiores hierárquicos, quanto pelos colegas de trabalho e até subordinados da vítima.

No que tange ao objetivo do agressor, no assédio sexual há a vontade de obter vantagem de cunho sexual da vítima, enquanto na violência perversa o objetivo é denegrir adignidade do assediado e o ambiente de trabalho.

Essa forma se assédio sexual não estabelece a necessidade de relação subordinativa entre os sujeitos ativo e passivo, não tem o caráter de chantagem nem está amparada pelo Direito Penal. Portanto, é a figura que mais se aproxima da violência perversa.

Evidentemente, são institutos os quais guardam entre si autonomia, embora em muitas situações fáticas podem se relacionar em problemática associação. 


\subsubsection{Assédio Moral x Poder Diretivo do Empregador}

Assim como a sociedade e os meios de produção, as relações de trabalho sofreram diversas modificações ao longo do tempo, de forma que no ordenamento jurídico atual são encontradas nas suas mais diversas espécies - desde o trabalho avulso ao contrato de empregopor prazo indeterminado.

Segundo Ricardo Rezende o contrato/relação de emprego - ao qual se limita o presente estudo, para ser caracterizado, necessita de seis elementos básicos, quais sejam:

Trabalho prestado por pessoa física: configurado quando há a exploração de energia de trabalho humana, de forma que só a pessoa natural pode ser empregada

Pessoalidade: dá ao vínculo de emprego natureza intuito personae do empregado em relação ao empregador, ou seja, o trabalhador é contratado para prestar seus serviços pessoalmente, não podendo ser substituído por outro, salvo em caráter esporádico e com a concordância do empregador.

Não eventualidade: dispõe que o empregado deve trabalhar de forma repetida nas atividades permanentes do empregador.

Onerosidade: existe, no contrato de emprego, a obrigação para o empregado de fornecer sua força de trabalho, e para o empregador, a obrigação de remunerar o empregado por seus serviços;

Alteridade: o empregado trabalha por conta alheia, ou seja, não corre o risco de negócio; e

Subordinação: requisito mais importante para caracterizar o vínculo de emprego eelemento diferenciador entre este e as demais relações de trabalho. O empregador, dono dos meios de produção e recursos, titular do comando da atividade, exerce o poder diretivo e direciona objetivamente a forma como o empregado usará sua energia de trabalho e este, por sua vez, se submete a tais ordens. E daí surge à subordinação. (grifos no original). (REZENDE, 2019, p. 66-74).

Esta é justamente a contraposição à autonomia; aquele que é subordinado, pois, não trabalha por conta própria, não é o senhor da sua força laboral. Dos seis requisitos que configuram a relação de emprego, a subordinação é o que marcou de maneira hegemônica 
os contratos de emprego na história ocidental (MUÇOUÇAH, 20I7), sempre configurado em uma limitação da liberdade do empregado, no que tange ao exercício de sua função laboral.

Vale ressaltar o fato de a doutrina, atualmente, ser unanime a respeito da natureza dessa subordinação, a qual é jurídica e derivada do contrato de trabalho. (REZENDE, 2019).

A manifestação desse elemento o qual caracteriza a relação de emprego é o poder diretivo do empregador.

Por sua vez esse poder diretivo é conceituado por alguns doutrinadores como uma faculdade do empregador de comandar a atividade do empregado no ambiente laboral. Por exemplo, Amauri Nascimento entende o poder diretivo como "a faculdade atribuída ao empregador de determinar o modo como a atividade do empregado, em decorrência do contrato de trabalho, deve ser exercida" (NASCIMENTO, 2017), enquanto Süssekind ensina que o trabalhador tem a obrigação de se deixar dirigir pelo empregador "segundo os fins que este se propõe a alcançar no campo da atividade econômica". (SÜSSEKIND, 2017).

Esse poder diretivo do empregador encontra limites nos direitos fundamentais do empregado, de forma que quando esses são ultrapassados, incide a figura do assédio moral, desde que o empregado seja submetido a condutas humilhantes, injustas e repetitivas, as quaisferem diretamente sua dignidade.

Não caracterizada a conduta abusiva, repetitiva e prolongada, de natureza psicológica, que atordoasse a saúde da trabalhadora, com situações humilhantes e constrangedoras, afasta- se o alegado assédio moral, porquanto a questão situa-se dentro do poder diretivo do empregador. DANO MATERIAL. LUCRO CESSANTE. A caracterização do lucro cessante exige um juízo de probabilidade objetiva de ganho patrimonial, e não mera expectativa de lucro hipotético e imaginário.

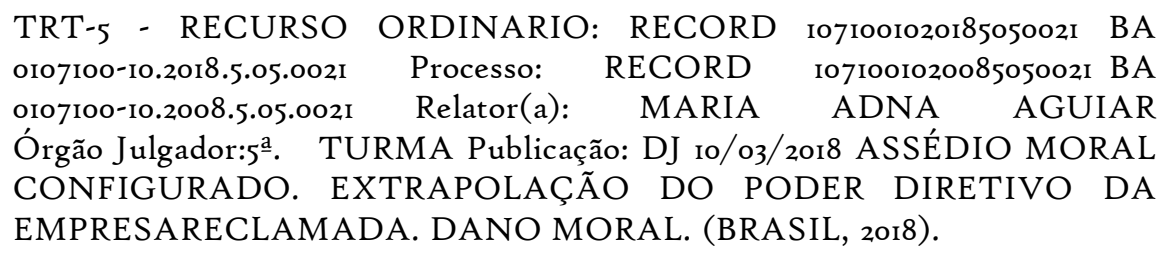


Os fatos narrados na inicial foram comprovados na instrução, em que restou demonstrado, a aplicação de sanções indevidas e injustas, atitudes que não deixam dúvidas acerca da forma desrespeitosa como eram tratado o reclamante, sendo atingindo naquilo que tem de mais valioso, a sua dignidade, desse modo, evidenciado o dano moral sofrido, e o constrangimento que lhe fora causado.

O poder diretivo do empregador se desdobra no poder de controle, no poder disciplinare no poder de organização, para a manutenção e ordem da entidade empregadora.Mas ele não é ilimitado, uma vez que encontra seus limites na própria CLT. Assim, acaso o empregador exorbite esse poder de mando e gestão, pode restar configurado o assédio moral, desde que o empregado tenha sido submetido a tratamento humilhante e desumano, numa evidente violação à dignidade da pessoa humana.

\subsubsection{Assédio moral e sua relação com outros institutos}

Com os avanços dos estudos no âmbito das relações de trabalho, o assédio moral passou a ser gênero do qual se ramificaram diversos institutos, cujos diferenciais doutrinários são a forma ou local em que o assédio é praticado.

Para Sergio Pinto Martins (2017, p.23), os principais são o mobbing e o bullying. O primeiro se diferencia por sempre ser praticado por grupo, já que o assédio moral pode ter como sujeito ativo tanto um grupo, quanto uma pessoa, apenas.

Já o bullying está relacionado ao ambiente escolar, sendo caracterizado, segundo o sitePortal do Bulying, por comportamentos agressivos, intencionais e repetitivos, praticados por um ou mais alunos contra outro. É exteriorizado através de insultos, gozações, apelidos cruéis etc. (PEIAS, 2019).

\section{APRESENTAÇÃO, ANÁLISE E DISCUSSÃO DOS RESULTADOS}

\section{I. Fases, dano causado pelo assédio moral, e tratamento do instituto no ordenamento jurídico brasileiro/clt \\ 4.1.1. Fases}

Por ser um processo de natureza psicológica muito abrangente e de difícil constatação, definir uma sequência em que haja o início, o desenvolvimento e o fim do assédio moral é uma tarefa bastante complexa. 
Serão apresentados aqui dois posicionamentos doutrinários complementares, em relação ao tema.

O primeiro de Leymann (2018), o qual destaca a existência de quatro fases para o assédio moral, sendo elas:

A - Fase de Conflito (incidente crítico original): está dentro da normalidade das relações humanas a existência de atritos interpessoais. A problemática surge a partir do momento em que não há flexibilização das opiniões, fazendo aparecer rivalidadee uma cadeia de enfrentamentos no ambiente de trabalho, causando mal estar. É umafase anterior ao assédio propriamente dito;

B - Fase de mobbing: o início e o desenvolvimento do assédio moral acontecem nestafase, na qual o assediador dá início a um conjunto de condutas psicológicase sistemáticas que tem o objetivo de humilhar a vítima, atingindo sua dignidade e reputação, bem como de denegrir o ambiente de trabalho. Pode contar, ou não com oapoio ativo ou passivo do meio. Esse comportamento do agressor perdura no tempo, fazendo com que o assediado fique estigmatizado. A fase de mobbing também é chamada de fase da estigmatização.

C - Fase de intervenção da empresa (administração de pessoal): ocorre quando a empresa tem conhecimento da pratica de violência perversa contra um de seus empregados, tomando, assim, uma atitude para solucionar o conflito.

D - Fase da expulsão: seria a última fase do assédio moral, em que o agressor consegue fazer com que o assediado deixe seu emprego por não suportar mais as humilhações. A saída da vítima pode ser precedida de diversos períodos de licença médica. (LEYMANN, 2018 p. II9-126),

Já para Sérgio Pinto Martins, fenômeno em questão possui cinco fases, as quais devemse apresentar na seguinte ordem:

$\mathrm{Na}$ primeira fase, o agressor decide quem será sua vítima; em seguida, na segunda fase, inicia-se o assédio propriamente dito, através do questionamento das capacidades profissionais do assediado, do isolamento etc. Acontecem as práticas que visam a desestabilizar emocionalmente o agredido.

A terceira fase consiste na permanência do isolamento da vítima e da aparição dos primeiros sintomas físicos decorrentes do estresse causado pela violência perversa. Já a quarta fase tem como característica o início das faltas do agredido ao trabalho, em decorrência dos problemas psicológicos e físicos oriundos da violência a que ésubmetido no ambiente laboral.

Por sua vez, a quinta e última fase é aquela na qual o assediado pede para sair ou abandona o emprego por não suportar mais as agressões sofridas. (MARTINS, 2017, p. 39-40)

É importante ressaltar que alguns chefes se tornam agressores a trabalhadores por serem constantemente pressionados pelas empresas para se cumprir determinadas metas. Neste caso, o problema de assédio moral é um problema estrutural da empresa.

O assédio moral, no entanto, pode estar também no rol das ações específicas a 
serviço da impropriedade. Um chefe ou diretor pode, ao observar a possibilidade de ser denunciado por alguma atitude imoral ou ilegal, demandar pressão sobre os prováveis denunciantes, como forma de calar, ou sobre todo um grupo, como forma de incutir o temor face à possibilidade de retaliação.

\subsection{Danos decorrentes do assédio moral e a CLT 4.2.I. Dano Moral}

Primordialmente, faz-se necessário não confundirmos a causa com seus efeitos. $O$ calor não é a queimadura, embora seja sua causa. Da mesma forma, a violência perversa, apesar de não ser o dano, provoca-o diretamente.

Se o assédio psicológico é a ação repetitiva que tem por objetivo violar a dignidade do agredido, o dano moral consiste no efeito dessa conduta.

Um dano ao patrimônio é aquele decorrente de uma ofensa a um bem corpóreo, o dano moral seria aquele oriundo de um prejuízo aos bens impassíveis de valoração financeira, como a dignidade da pessoa humana, em sua versão mais ampla.

Consiste no resultado de uma lesão no âmbito mais íntimo do ser, no seu valor próprio interno (dignidade). Valor este de tal importância no nosso ordenamento jurídico que encontralugar como fundamento da própria Democracia Nacional, como vemos no art. Io, inciso III, daConstituição da República:

\footnotetext{
Art. Io A República Federativa do Brasil, formada pela união indissolúveldos Estados e Municípios e do Distrito Federal, constitui-se em Estado Democrático de Direito e tem como fundamentos: III - a dignidade da pessoa humana; [...] (BRASIL, 1988).
}

É importante notarmos o fato de a violência perversa não apenas atingir os direitos à integridade moral ou psíquica da vítima, mas lesionar toda uma gama de direitos à personalidade, quais sejam, os direitos à liberdade, à honra, à segurança moral, à igualdade etc. Inclusive, a depender da gravidade, viola o próprio direito ao trabalho do assediado.

Vale ressaltar que alguns doutrinadores, como Carlos Roberto Gonçalves, se filiam a corrente de ser o dano moral a própria causa da lesão/lesão em si, não seu resultado. Seguindo esse raciocínio, ensina que dano moral é o que atinge o ofendido como pessoa, não lesando seu patrimônio. É lesão de bem que integra os direitos da personalidade, como a honra, a dignidade, intimidade, a imagem, o bom nome, etc., como 
se infere dos art. Ioㅡ, III, e $5^{\circ}, \mathrm{V}$ eX, da Constituição Federal, e que acarreta ao lesado dor, sofrimento, tristeza, vexame e humilhação. (GONÇALVES, 2018).

Contudo, por questão de posicionamento e por pensarmos estar mais de acordo com nossos anseios, seguimos a corrente apresentada no início desse tópico; ao separarmos causa eefeito, abrimos, pois, a possibilidade de imputar mais facilmente a responsabilidade ao agressor.

Nesse sentido, Youssef Cahali ensina:

Dano moral, portanto, é a dor resultante da violação de um bem juridicamente tutelado, sem repercussão patrimonial. Seja dor física - dor- sensação, como a denominada Carpenter - nascida de uma lesão material; seja a dor moral - dorsentimento, de causa imaterial. (CAHALI, 2018, p. 28).

$\mathrm{O}$ dano em estudo pode ser classificado em direto ou indireto. $\mathrm{O}$ primeiro tem seu fundamento em lesão a um bem jurídico extrapatrimonial, exclusivamente. Já o dano indireto ou por ricochete acontece quando um bem corpóreo é atingido e isto gera repercussões também na esfera moral. (MUÇOUÇAH, 20I8, p. I48).

Encontramos no nosso ordenamento jurídico a obrigação de reparar o prejuízo causadono art. 927, caput, do Código Civil:

Art. 927. Aquele que, por ato ilícito (arts. 186 e 187), causar dano a outrem, fica obrigado a repará-lo. (BRASIL, 2002).

Obeserva-se que o art. Acima descrito, impõe aquele que vier por de um ato ilícito causar dano à outra pessoa, será obrigado a repará-lo.

\subsection{Novos artigos inseridos na CLT em decorrência do dano moral eextrapatrimonial}

A lei $n^{0}$ 13.467/2017 introduziu na CLT os artigos 223-A até 223-G, na busca de determinar limite à interpretação do legislador quanto às possibilidades de indenizar a parte afetada pelo dano moral de corrente do assédio moral/ dano extrapatrimonial:

Art. 223- A - Aplicam-se à reparação de danos de natureza extrapatrimonial decorrentes da relação de trabalho apenas os dispositivos deste Título.

Art. 223-B - . Causa dano de natureza extrapatrimonial a ação ou omissão que ofenda a esfera moral ou existencial da pessoa física ou jurídica, as quais são as titulares exclusivas do direito à reparação.

Art. 223-C - A honra, a imagem, a intimidade, a liberdade de ação, a autoestima, a sexualidade, a saúde, o lazer e a integridade física são os bens 
juridicamente tutelados inerentes à pessoa física.'

'Art. 223-D - A imagem, a marca, o nome, o segredo empresarial e o sigilo da correspondência são bens juridicamente tutelados inerentes à pessoa jurídica.

Art. 223- E - São responsáveis pelo dano extrapatrimonial todos os que tenham colaborado para a ofensa ao bem jurídico tutelado, na proporção da ação ou da omissão.

Art. 223- F - A reparação por danos extrapatrimoniais pode ser pedida cumulativamente com a indenização por danos materiais decorrentes do mesmo ato lesivo.

§ I Se houver cumulação de pedidos, o juízo, ao proferir a decisão, discriminará os valores das indenizações a título de danos patrimoniais e das reparações por danos de natureza extrapatrimonial.

$\S 2^{\circ}$ A composição das perdas e danos, assim compreendidos os lucros cessantese os danos emergentes, não interfere na avaliação dos danos extrapatrimoniais.'

Art. 223-G. Ao apreciar o pedido, o juízo considerará:

I - a natureza do bemjurídico tutelado;

II- a intensidade do sofrimento ou da humilhação;

III- a possibilidade de superação física ou psicológica;

IV - os reflexos pessoaise sociais da ação ou da omissão;

$V$ - a extensão e a duração dos efeitos da ofensa;

VI - as condições em que ocorreu a ofensa ou o prejuízo moral;

VII - o grau dedolo ou culpa;

VIII - a ocorrência de retratação espontânea;

IX - o esforço efetivo paraminimizar a ofensa; X - o perdão, tácito ou expresso;

$X I$ - a situação social e econômica das partes envolvidas;

XII - o grau depublicidade da ofensa.

§ $I^{\circ}$ Se julgar procedente o pedido, o juízo fixará a indenização a ser paga, a cadaum dos ofendidos, em um dos seguintes parâmetros, vedada a acumulação:

I - ofensa de natureza leve, até três vezes o último salário contratual do ofendido;

II - ofensa de natureza média, até cinco vezes o último salário contratual do ofendido;

III - ofensa de natureza grave, até vinte vezes o último salário contratual doofendido;

$I V$ - ofensa de natureza gravíssima, até cinquenta vezes o último salário contratualdo ofendido.

$\S 2^{\circ} \mathrm{Se}$ o ofendido for pessoa jurídica, a indenização será fixada com ervância dos mesmos parâmetros estabelecidos no $\S I^{\circ}$ deste artigo, mas em relação ao saláriocontratual do ofensor.

$\S 3^{\circ} \mathrm{Na}$ reincidência entre partes idênticas, o juízo poderá elevar ao dobro o valor daindenização. (BRASIL, 2017).

Nos termos do art. 223-C, é explanado que tanto a honra, a imagem, a intimidade, a 
liberdade de ação, a autoestima, a sexualidade, a saúde, o lazer e a integridade física esses são os bens juridicamente tutelados inerentes à pessoa física (GUELLER, 2019). Observase que não foram explanados na reforma trabalhista o preconceito racial ou religioso dentre as hipóteses deste artigo, pois sabe-se que é muito comum na seara laboral. Porém, esses direitosestão protegidos pela Constituição Federal de 1988 em seu art. $5^{\circ}$.

Já o art. 223-D declara que a imagem, a marca, o nome, o segredo empresarial e o sigilo da correspondência são bens juridicamente tutelados inerentes à pessoa jurídica. Oart. 223-E afirma que serão responsáveis pelo dano extrapatrimonial todos os que tenham auxiliado para a ofensa ao bem jurídico tutelado, na medida da ação ou omissão, e o artigo 223-F prevê que a reparação por danos extrapatrimoniais pode ser pedida cumulativamente com a indenização por danos materiais decorrente do mesmo ato lesivo. (GUELLER, 2019).

Diante do contexto do art. acima citado, ele prevê a natureza do bem jurídico protegido, bem como as condições do sofrimento ou da humilhação da vítima, a viabilidadede superação física ou psicológica, o grau de dolo e da culpa, a possibilidade de retratação para diminuir a ofensa.

Contudo, observa-se que nos termo do referido art. 223-G em seu parágrafo ${ }^{\circ}$, prevê que o magistrado fixará o pedido eventualmente procedente com base nos seguintes critérios: se tratar-se de ofensa de natureza leve, até três vezes o último salário contratual doofendido; se ofensa de natureza média, até cinco vezes o último salário contratual do ofendido; se de natureza grave, até vinte vezes o último salário contratual do ofendido; e, por fim, se de natureza gravíssima, até cinquenta vezes o último salário contratual do ofendido. (BRASIL, 2017).

Dessa forma, pode-se concluir que existe a possibilidade de que, quem ganha mais terá direito a maior indenização, o que, infelizmente, não corresponde ao mundo fenomênico frequentemente. Em fim, com base na Lei n. 13.467/2017 (Lei da Reforma Trabalhista), a aplicabilidade desses artigos relacionados ao dano moral e extrapatrimonial poderão ser aplicados em benefício da vítima em uma ação de assédio moral na seara laboral. 


\subsection{Dano psíquico, dano existencial e dano físico}

O dano moral varia de intensidade conforme o caso e a pessoa.

A agressão pode ser grave a ponto de atingir a integridade psicológica da vítima, de forma que the cause uma profunda perturbação em seu equilíbrio sócio-emocional, alterando significativamente sua interação com o meio, sua personalidade e seu comportamento.

Esse dano de cunho patológico recebe a denominação de dano psíquico e segundo Geraldo José Ballone:

$$
\begin{aligned}
& \text { Se caracteriza por um prejuízo emocional capaz de resultar em } \\
& \text { comprometimentodas funções psíquicas, de forma súbita e inesperada, surgida } \\
& \text { após um evento traumático (ação deliberada ou culposa de alguém e que traz } \\
& \text { para a vítima um prejuízo material ou moral decorrente da limitação de suas } \\
& \text { atividades habituais oulaborativas) (BALLONE, 2org, p. 3). }
\end{aligned}
$$

Há autores, como Hernán Daray (2017), para os quais os danos moral e psíquico devem ser diferenciados; o segundo, pois, além de apresentar um cunho patológico, possui umtratamento diverso do primeiro quanto à natureza da condenação, aos parâmetros para sefixar o valor indenizatório e aos meios de prova.

Vemos o dano psíquico na qualidade de espécie do dano moral, ou como o próprio dano moral quando se aprofunda ao ponto de ter consequências patológicas, as quais afetama percepção individual de mundo da vítima. Não concordamos com diferenciações, seguindo o entendimento de Renato Muçouçah. (2018).

Por sua vez, o dano existencial é mais complexo e profundo.

Ocorre quando um evento gera em alguém um dano imaterial de tamanha magnitude que torna esta pessoa incapaz de prosseguir com seu projeto de vida, por exemplo, detrabalhar novamente, de manter relações sociais com sua família e amigos, etc. Como se um acontecimento tomasse toda a capacidade da vítima de viver, causando-lhe umvazio existencial.

Nas palavras de Flaviana Rampazzo, o dano existencial deve ser conceituado como a lesão ao complexo de relações que auxiliam no desenvolvimento normal da personalidade do sujeito, abrangendo a ordem pessoal ou a ordem social. É uma afetação negativa, total ou parcial, permanente ou temporária, seja a conjunto de atividades que a vítima do dano, normalmente, tinha como incorporado ao cotidiano e que, em razão do efeito lesivo, 
precisou modificar em sua forma de realização, ou mesmo suprimir sua rotina. (SOARES, 2018).

Já para Júlio César Bebber, no conceito de dano existencial:

Compreende-se toda lesão que compromete a liberdade de escolha e frustra o projeto de vida que a pessoa elaborou para sua realização como ser humano. Diz- se existencial exatamente porque o impacto gerado pelo dano provoca um vazio existencial na pessoa que perde a fonte de gratificação vital. Por projeto de vida entenda-se o destino escolhido pela pessoa; o que decidiu fazer com sua vida. Por isso, as pessoas permanentemente projetam o futuro e realizam escolhas no sentido de conduzir sua existência à realização do projeto de vida. O fato injusto que frustra esse destino (impede a sua plena realização) e obriga a pessoa a resignar-se com o seu futuro é chamado de dano existencial. (BEBBER, 2017, p. 26-29).

De acordo com os ensinamentos de Renato Muçouçah (2018) haveria uma diferença entre o dano existencial e o dano moral, pois este se trata fundamentalmente de um sentir, enquanto aquele consiste em uma incapacidade de fazer.

Por fim, vale ressaltar o fato de as consequências da violência perversa ultrapassarem as fronteiras psicológicas ocasionando, muitas vezes, um dano físico às vítimas.

Essa lesão decorre do estresse e da pressão impostos ao agredido e se manifesta nas mais variadas formas, por exemplo, ansiedade generalizada, fadiga crônica, agressividade repentina, dores de cabeça, dores múltiplas, insônia, taquicardia, distúrbios psicossomáticos diversos - hipertensão arterial, úlcera, crises de choro, depressão e tendências suicidas, sintomas que se aproximam do estresse pós-traumático e, também, através de condutas de dependência, como bulimia, alcoolismo, toxicomania etc. (HIRIGOYEN, 2018).

\subsection{Da Prova do Assédio Moral}

É notória a dificuldade de se provar a prática da violência perversa, tendo em vista ser uma conduta de natureza psicológica.

O Direito do Trabalho tem como mandamento basilar o Principio in dúbio pro operário ou in dúbio pro misero, segundo o qual, caso haja dúvida quanto à interpretaçãoda regra ou em face do conjunto probatório, o julgador deve decidir de forma mais favorável ao trabalhador. (REZENDE, 2019). 
No âmbito do assédio moral, esse princípio não deve ser aplicado. Não pode o fenômeno em estudo ser presumido em uma relação trabalhista, pois, além de ser obrigação do empregador manter a higidez do ambiente laboral, todo e qualquer tipo de contrato incluso também o de trabalho é regido pelo princípio da boa-fé objetiva, nos termos do artigo 422 do Código Civil:

Art. 422. Os contratantes são obrigados a guardar, assim na conclusão do contrato, como em sua execução, os princípios de probidade e boa-fé. (REZENDE, 2019).

Dessa forma, o ônus da prova é do empregado, até por se tratar de direito constitutivo seu, nos termos dos artigos 8I8 da CLT e 313, inciso I, do Código de Processo Civil:

Art. 818 - A prova das alegações incumbe à parte que as fizer.

Art. 333. O ônus da prova incumbe:

[...] - ao autor, quanto ao fato constitutivo do seu direito; [...].

Para tanto, todos os meios de prova serão admissíveis, desde que moralmente legítimos, por exemplo, documentos, testemunhas, imagens etc.

A única polêmica quanto à prova do assédio moral diz respeito à possibilidade de gravação de conversas sem o conhecimento do agressor. A jurisprudência vem aceitando a legalidade das gravações, devido ao fato de a vítima usá-las para defender interesse próprio. Vejamos:

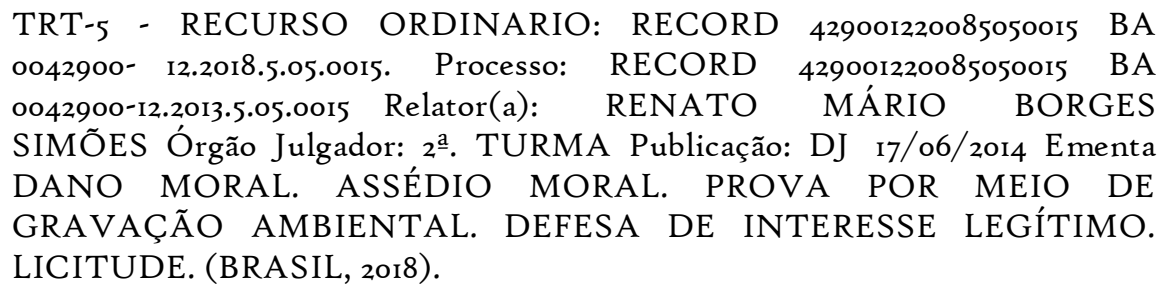

Vaale ressaltaria que a jurisprudência do Supremo Tribunal Federal é assente no entendimento de que a gravação ambiental realizada por iniciativa de um dos interlocutores, ainda que sem conhecimento do outro, nada tem de ilicitude, notadamente quando se destina a documentá-la em caso de negativa e defesa de interesse legítimo.

TST - RECURSO DE REVISTA: RR 2015002220195070001 20150022.2019.5.07.0001. Processo: RR 2015002220195070001 201500-

22.2017.5.07.0oor. Relator (a): Emmanoel Pereira Julgamento: o8/o8/2019 Órgão Julgador: $5^{\text {a }}$ Turma Publicação: DEJT i7/o8/2019 [...] ASSEDIO MORAL. 
CARACTERIZAÇÃO. GRAVAÇÃO AMBIENTAL. PROVA. LICITUDE. MONTANTE. (BRASIL, 2017).

$\mathrm{Na}$ esteira do entendimento do Supremo Tribunal Federal e do Tribunal Superior do Trabalho, é válida a gravação ambiental por parte de um dos interlocutores como meio de prova. O Tribunal Regional deixa patente que a gravação realizada pela empregada demonstraa sugestão do empregador de ajuizamento de lide simulada como condição para satisfação doscréditos rescisórios da trabalhadora, restando demonstrado o assédio moral.

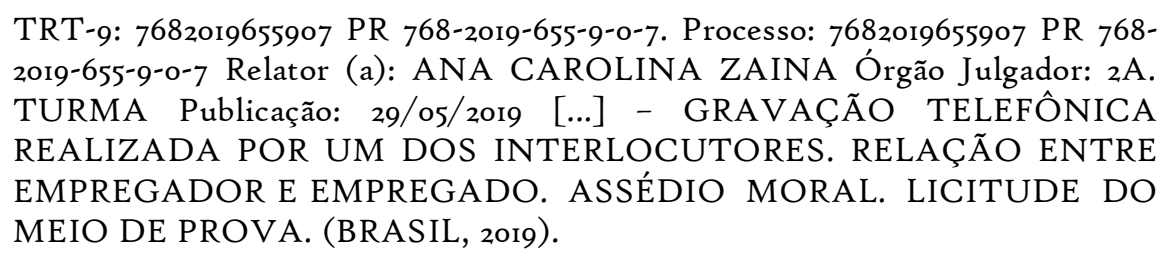

A gravação telefônica, desde que realizada por um dos interlocutores, é meio de provalícito e independe, para sua validade ou licitude, de autorização do outro interlocutor.

Não há ofensa aos incisos XIII e LVI do art. $5^{\circ}$ da Carta Maior. Precedentes no mesmo sentido do C. STF.

\subsubsection{Prescrição do Assédio Moral}

Por ser um conflito de origem trabalhista e de competência da Justiça do Trabalho, submete-se a lide à prescrição quinquenal, durante o curso do contrato de trabalho, e de dois anos, após o término do vínculo empregatício, conforme disposição do artigo $7^{\circ}$, inciso XXIX, da Constituição Federal:

Art. $7^{\circ}$ São direitos dos trabalhadores urbanos e rurais, além de outros que visem à melhoria de sua condição social:

XXIX - ação, quanto aos créditos resultantes das relações de trabalho, com prazo prescricional de cinco anos para os trabalhadores urbanos e rurais, até o limite de dois anos após a extinção do contrato de trabalho; (Redação dada pela Emenda Constitucional no 28, de 25/05/2000). (BRASIL, 2000).

No mesmo sentido, o Tribunal Superior do Trabalho dispõe:

TST - RECURSO DE REVISTA: RR 7680092200850906557680092.2008.5.09.0655. RECURSO DE REVISTA. Processo:RR

76800922008509065576800-92.2017.5.09.0655 Relator (a): Mauricio

Godinho. Delgado Julgamento: 14/o9/2015 Órgão Julgador: 6 ${ }^{\underline{a}}$ Turma 
Publicação: DEJT 23/09/2017 [...] 2. PRESCRIÇÃO. ASSÉDIO MORAL. Aplica-se o critério da Constituição (art. $7^{\circ}$, XXIX), isto é, prescrição quinquenal, respeitados dois anos do fim do contrato. Fundamenta este entendimento o fato de as indenizações por dano patrimonial, moral, inclusive estético, serem efeitos conexos do contrato de trabalho (ao lado dos efeitos próprios deste contrato), todos submetidos à mesma regra do art. $7^{-}$, XXIX,da Carta Magna. Independentemente do Direito que rege as parcelas (no caso, Direito Civil), todas só existem porque derivadas do contrato empregatício, submetendo-se à mesma prescrição. Esta é, pois, a regra geral aplicável às ações trabalhistas, propostas perante a Justiça do Trabalho, mesmo versando sobre dano patrimonial, moral ou estético oriundo de doença profissional/ocupacional ou acidente do trabalho (art. $7^{\circ}$, XXIX, CF/88). (BRASIL, 2017).

Verifica-se que, conforme consignado pelo Regional, o Reclamante pretende a condenação das rés ao pagamento de indenização por danos morais decorrentes da pressão sofrida durante o contrato de trabalho firmado com a primeira Reclamada, para que fizesse acordo ou desistisse da demanda trabalhista ajuizada em face da segunda Ré. Assim, tendo o assédio moral ocorrido durante o contrato de trabalho, que findou em junho/2007, e tendoa presente demanda sido proposta em 20/8/2008, não se há falar em prescrição bienal. Recurso de revista não conhecido, no particular.

\section{CASO PRÁTICO E TRATAMENTO DO ASSÉDIO MORAL NO ORDENAMENTO JURÍDICO BRASILEIRO 5.I. Caso prático}

Em São Paulo, grande parte dos profissionais brasileiros pratica ou tolera assédio em seu ambiente de trabalho, segundo um levantamento realizado pelo IPRC (Instituto de Pesquisa do Risco Comportamental). (LIMA, 202I, p. I).

Como o assédio pode se manifestar de muitas formas, desde a violência psicológica até a sexual, o levantamento foi subdividido em três temas: assédio moral, assédio sexual e corporativismo.

Os dados indicaram que $41 \%$ dos profissionais se omitiriam na vivência ou no conhecimento da ocorrência de assédio moral. Quando se trata de assédio sexual esse número vai para 37\%. (LIMA, 2021, p. I).

No levantamento, cerca de $37 \%$ dos profissionais apontam alta resistência quando 
deparam com dilemas que envolvem assédio moral, ou seja, não aceitam a prática que ocorre na organização.

Assim, vejamos um caso prático de assédio sexual julgado pelo TRT da $4^{\underline{a}}$ Região onde uma funcionária de uma empresa do ramo de supermercados ingressou com reclamação trabalhista em desfavor da empresa narrando que sofreu humilhação no ambiente de trabalho por ter sido vítima de assédio pelo seu superior hierárquico, o qual praticava tentativas absurdas e incansáveis de que a trabalhadora pedisse dispensa ou queriaobter vantagem sexual. (KREBS, 2021, p. 12).

Referiu ainda que o gerente da loja da empresa fez insinuações no ambiente de trabalho que constrangeram a reclamante, sendo que por várias vezes tais elogios vêm acompanhados de toques nos cabelos e no corpo.

Diante da conduta de seu funcionário, a empresa foi condenada ao pagamento de indenização pelo dano moral causado à sua ex-funcionária no valor de $\mathrm{R} \$$ I0.00o,oo (dez mil reais). (KREBS, 2021, p. I2).

Infelizmente, há centenas de casos como este que tramitam na Justiça do Trabalho brasileiro, nos quais juízes se deparam com muitos casos de assédio em suas mais variadas formas, aos quais os trabalhadores são submetidos. $\mathrm{O}$ valor das indenizações geralmente varia entre $R \$ 5$ mil e $R \$ 20$ mil, embora esses valores possam ser muito diferentes de acordo com o entendimento de cada juiz, ao considerar o capital social da empresa assediadora e o salário do trabalhador. (KREBS, 2021, p. 12).

Concluindo, à luz da legislação vigente, todos os tipos de assédio, tanto moral quantosexual, fazem presente nas relações de trabalho, e, portanto, torna-se imprescindível análise criteriosa e com maior rigor sobre o tema, até mesmo em relação ao direito penal, de maneira que firma apunição sob a forma de indenização trabalhista, exigindo das empresas total atenção para a questão com medida para se evitar eventual responsabilização perante o judiciário. Ainda não há no âmbito federal uma Lei que regulamente o fenômeno em estudo na esfera trabalhista. Não há definição legislativa, muito menos estabelecimento de pena. Há, entretanto, leis e projetos de lei esparsos, os quais visam à repressão da violência perversa, tendo como exemplo:

Lei II.948/2009 - em seu artigo $4^{\text {o }}$ veda a concessão de empréstimos do BNDES a 
empresas cujos dirigentes foram condenados por assédio moral e afins:

Art. $4^{\circ}$ Fica vedada a concessão ou renovação de quaisquer empréstimos ou financiamentos pelo BNDES a empresas da iniciativa privada cujos dirigentes sejamcondenados por assédio moral ou sexual, racismo, trabalho infantil, trabalhoescravo ou crime contra o meio ambiente. (BRASIL, 2009).

Projeto de Lei 4.326, de 2004 - pretende instituir o dia 02 de maio de cada ano como Dia Nacional de Luta Contra o Assédio Moral (MANINA, 2or8, p. 8).

Projeto de Lei 5.970, de 2001 - visava à alteração do artigo 483, da CLT, e inclusão do art. 484-A, no mesmo instrumento legal, no seguinte teor:

CÂMARA DOS DEPUTADOS Projeto de lei federal no 5.970/2001 O CongressoNacional decreta:

Artigo Io - O art. 483 do Decreto-Lei n.o 5.452, de Io de maio de 1943 Consolidação das Leis do Trabalho, passa a vigorar acrescido da alínea "g", coma seguinte redação:

“Art. 483 [...]

a) praticar o empregador ou seus prepostos, contra ele, coação moral, através de atosou expressões que tenham por objetivo ou efeito atingir sua dignidade e/ou criar condições de trabalho humilhantes ou degradantes, abusando da autoridade que the conferem suas funções. (BRASIL, 200I).

Art. $2^{2}$ - $-\mathrm{O} \S 3^{\circ}$ do art. 483 da CLT - Consolidação das Leis do Trabalho, passa a vigorar com a seguinte redação:

“§ 3 Nas hipóteses das letras d, g e h, poderá o empregado pleitear a rescisão de seu contrato e o pagamento das respectivas indenizações, permanecendo ou não no serviço até final decisão do processo. (BRASIL, 2017)."

Art. $3^{\text {o }}$ - Acrescente-se o art. 484-A ao Decreto-Lei n.ㅇ 5.452, de I을 de maio de 1943 - Consolidação das Leis do Trabalho, com a seguinte redação:

"Art. 484 - A Se a rescisão do contrato de trabalho foi motivada pela prática de coação moral do empregador ou de seus prepostos contra o trabalhador, o juiz aumentará, pelo dobro, a indenização devida em caso de culpa exclusiva do empregado." (ARRUDA, 2017, p. 44).

Projeto de Lei 4742/2001 - cria o art. 136-A, no Código Penal, criminalizando a conduta do assédio moral, nos seguintes termos:

Artigo Io - O Decreto-Lei no 2.848 , de 7 de dezembro de 1940, Código Penal Brasileiro, fica acrescido do art. 136-A, com a seguinte redação:

Art. 136-A. Depreciar, de qualquer forma e reiteradamente a imagem ou o desempenho de servidor público ou empregado, em razão de subordinação hierárquica funcional ou laboral, sem justa causa, ou tratá-lo com rigor excessivo,colocando em risco ou afetando sua saúde física ou psíquica.

Pena - detenção de um a dois anos.

Art. $2^{-}$- Esta lei entra em vigor na data de sua publicação. (JESUS, 2019, p. 55). 
Se o servidor já sofreu o assédio moral, este deve procurar conversar com um superior responsável para tomar medidas necessárias de proteção contra esse problema. E se mesmo assim continuar sendo assediado, o empregado deve buscar ajuda com a justiça e medidas mais rigorosas.

\section{CONSIDERAÇÕES FINAIS}

Devido à modernização das empresas e do aumento da concorrência, é obrigatório que os empregados tenham autos níveis de produtividade e desempenho. $\mathrm{O}$ assédio moral não é um tema novo, por ser oriundo das relações de trabalho, no entanto, pesquisas sobre a matéria se iniciaram na década de 1960 e, mais especificamente, sobre a violência perversa no ambiente de trabalho, na década de 1980.

Conceituamos assédio moral no ambiente de trabalho como conduta de natureza psicológica, praticada no ambiente laboral ou no exercício das funções, de forma repetitiva e injusta, cujo objetivo é constranger o assediado, causando ofensa diretamente à dignidade, à personalidade, à integridade psíquica do ofendido e, de forma indireta, a sua integridade física.

Dessa forma, os elementos caracterizadores do assédio moral são: conduta de natureza psicológica; a prática da conduta deve ocorrer no ambiente de trabalho ou quando o empregado esteja no exercício de suas funções; o comportamento do agressor deve se repetir ao longo do tempo; é necessária a existência de dano e nexo causal entre as atitudes do assediador e prejuízo do agredido.

Por ser uma conduta originária de uma relação trabalhista, a competência é da Justiça do Trabalho, por determinação do art. II4, inciso I, da Constituição Federal de 1988.

Existem diversos tipos de sujeito ativo da conduta crítico, sádico, tirano etc., podendo ser o superior ou inferior hierárquico da vítima, bem como seu(s) colega(s) de trabalho. Já o sujeito passivo deve fazer parte do quadro de empregados da empresa.

As principais espécies de assédio moral são o assédio moral vertical quando a conduta é praticada por superior ou inferior hierárquico da vítima; o assédio moral horizontal cometido por agressor de mesma hierarquia funcional da vítima; e o assédio moral misto praticado por superior ou inferior e, ao mesmo tempo, por colegas de mesma 
hierarquia do agredido. Existem outras espécies de violência perversa destacadas pela doutrina, como abordamos no ponto 2.2, dentre as quais, o assédio moral individual, coletivo, institucional, estratégico etc.

Fenômenos como o assédio sexual e o poder diretivo do empregador podem ser confundidos com a violência psicológica praticada no ambiente de trabalho. O primeiro, no entanto, tem sua principal diferença na vontade do agressor obter uma vantagem de cunho sexual da vítima; no modus operandi o sujeito ativo utiliza de chantagem para alcançar seus objetivos; e pelo fato de apenas o superior hierárquico da vítima ou quem lhe faça às vezes poder praticar a conduta.

Quanto ao poder diretivo do empregador, consiste em uma capacidade a qual the pertence exclusivamente, de comandar o curso das atividades produtivas através da direção, fiscalização e regulamentação da atividade, como também de seu poder punitivo. De acordo com a doutrina e a jurisprudência o empregador, não pode, jamais, utilizar dessas prerrogativas para violar os direitos fundamenteis do empregado, sob pena de configuração doassédio moral.

Como conjunto de atitudes, a violência perversa apresenta fases, as quais consistem basicamente na escolha da vítima, devido a conflitos internos ou motivos pessoais do agressor; no início das condutas psicológicas ofensivas; no isolamento do assediado e aparição dos sintomas oriundos do assédio; em faltas do empregado ao trabalho, em decorrência dos problemas psicológicos e físicos causados pela violência a que é submetidono ambiente laboral; e, finalmente, a saída da vítima da empresa.

O assédio moral tem por resultado uma diversidade de prejuízos imateriais ao assediado, quais sejam: o dano moral propriamente dito resultado de lesão a bem jurídico extrapatrimonial, a valores íntimos e próprios da vítima (sua dignidade); o dano psíquico dano moral que atinge a vítima de forma mais profunda e adquire um caráter patológico; dano existencial - lesão imaterial de tamanha magnitude que torna esta pessoa incapaz de prosseguir com seu projeto de vida; e o dano físico prejuízo que ultrapassa as fronteiras psicológicas, manifestando-se através de ansiedade generalizada, fadiga crônica, agressividade repentina, dores de cabeça, dores múltiplas, insônia, taquicardia, distúrbios psicossomáticos diversos hipertensão arterial, úlcera, crises de choro, depressão e 
tendências suicidas, sintomas que se aproximam do estresse pós-traumático e, também, através de condutas de dependência, como bulimia, alcoolismo, toxicomania etc.

Devido ao princípio da boa-fé nas relações contratuais e por ser obrigação do empregador manter a higidez do ambiente de trabalho, o assédio moral não pode ser presumido, restando o ônus da prova ao empregado. Esta se dá por todos os meios admitidos em direito, inclusive gravação de conversa própria, como visto no ponto 3.3.

Por ser um conflito de origem trabalhista e de competência da Justiça do Trabalho, submete-se a lide à prescrição quinquenal, durante o curso do contrato de trabalho, e de dois anos, após o término do vínculo empregatício, conforme disposição do artigo $7^{\circ}$, inciso XXIX, da Constituição Federal.

No âmbito legislativo, ainda não há lei federal própria que defina ou regulamente o instituto, apesar de existirem tentativas de coibir a prática do assédio moral no ambiente de trabalho. Dentre elas, a Lei II.948/2009, cujo artigo $4^{\underline{0}}$ veda a concessão de empréstimos do BNDES para empresas nas quais os dirigentes foram condenados por assédio moral e afins, e o Projeto de Lei 4.742/200I que visa à criação do art. 136-A do Código Penal, criminalizando o fenômeno em estudo.

Por ser competência privativa da União legislar sobre direito do trabalho, nos termos do art. 22, inciso I, da CRFB/88, os demais entes federativos só podem coibir a prática da violência perversa no ambiente de trabalho na esfera administrativa, por meio de leis que visam à proteção de seus respectivos servidores públicos civis.

Destaca-se, que a Lei da reforma trabalhista inseriu em seu texto os artigos 223-A até $223-\mathrm{G}$, com possibilidade de aplicabilidade desses artigos relacionados ao dano moral e extrapatrimonial os quais poderão ser aplicados em benefício da vítima em uma ação de assédio moral na seara laboral.

Portanto, devido à gravidade e às consequências negativas do assédio moral nas relações de trabalho, acreditamos ser mais que urgente a regulamentação da conduta, com o estabelecimento de penas para os agressores, através de uma lei própria.

\section{REFERÊNCIAS}

ARRUDA, Inácio. Projeto de Lei 5.970, de 2017. Disponível em: 
〈http://www.camara.gov.br/proposicoesWeb/prop_mostrarintegracodteor $=13756 \&$ filename $=\mathrm{PL}+5970 / 2001>$. Acesso em: 06 mar. 2021.

BAllone, Geraldo José; MOURA, E. C. Dano Psíquico. Disponível em $\langle$ http://www.psiqweb.med.br/site/?area=NO/LerNoticia\&idNoticia=192019〉. Acesso em: o6 mar. 2021.

BEBBER, Júlio César. Danos extrapatrimoniais (estético, biológico e existencial) - breves considerações. In: Revista LTr: legislação do trabalho, São Paulo, LTr, v. 73, n. I, janeiro, p. 26-29, 2017 .

BRASIL. LEI № 13.467, DE 13 DE JULHO DE 2017. Reforma Trabalhista. Disponível em: 〈http://www.planalto.gov.br/ccivil_03/leis/L8213cons.htm>. Acesso em: o8 mar. 202I.

BRASIL. CÓDIGO CIVIL, 2002. Disponível em: 〈http://www.planalto.gov.br/ccivil_03/leis/2002/lio406.htm> Acesso em: 20 ago. 202I.

. Lei no 11.948, de 16 de junho de 2009. Disponívelem: 〈http://www.planalto.gov.br/ccivil_03/_ato2007-2010/2009/Lei/Li194 8.htm>. Acesso em: IO mar. 2021.

- Tribunal Superior do Trabalho TST - RECURSO DE REVISTA: RR 11632820145090655. 2017. Disponível em: https://tst.jusbrasil.com.br/jurisprudencia/442365330/recurso-de-revista-rrII632820145090655/inteiro-teor-442365349.> Acesso em: io mar. 2021.

- Tribunal Regional do Trabalho da 9 $9^{\underline{a}}$ Região TRT-9: 7682019655907 PR 768-202-655-9-0-7. 2019. Disponível em:<https://trt.jusbrasil.com.br/jurisprudencia/r893872I/7682008655907-pr-768- 2019-655-90-7-trt-9.> Acesso em: Io mar. 2021. 
- TRT-5 - RECURSO ORDINARIO: RECORD 429001220185050015 BA

0042900-12.2018.5.05.0015.

Disponível

em:

〈https://trt5.jusbrasil.com.br/jurisprudencia/23602020I/recurso-ordinario-record-

5958920145050342- ba-0000595-8920185050342.> Acesso em: o8 mar. 2021.

. DECRETO-LEI $\mathrm{N}^{\circ}$ 2.848, DE 7 DE DEZEMBRO DE 1940.

Disponível em: 〈http://www.planalto.gov.br/ccivil_03/decreto-lei/Del2848.htm>. Acesso em: Io mar. 2021.

- CONSTITUIÇÃO DA REPÚBLICA FEDERATIVA DO BRASIL

DE i988. Disponível em:

http://www.planalto.gov.br/ccivil_03/constituicao/constituicaocompilado.htm. Acesso em: Iomar. 202I.

CAHALI, Yussef Said. Dano moral. São Paulo: Revista dos Tribunais, 2018. DARAY, Hernán. Daño psicológico. Buenos Aires: Astrea, 2017. p. 25-30.

GUELlER, Marta. O Dano Moral e a Reforma Trabalhista. 2017. Disponível em: 〈http://economia.estadao.com.br/blogs/o-seguro-morreu-de-velho/o-dano-moral-e-areforma-trabalhista/>. Acesso em: I7 mar. 202I.

HIRIGOYEN, Marie-France. Assédio moral: a violência perversa no cotidiano. Rio de Janeiro: Bertrand Brasil, 2016. p. 189-185.

. Mal-estar no trabalho: redefinindo o assédio moral. Rio de Janeiro: Bertrand Brasil, p. 17, 2017.

LEYMANN, Heinz. Mobbing and psychological terror at workplaces. Violence and Victims. 2018 p. II9-I26. Disponível em: 
http://www.mobbingportal.com/LeymannV\&Vig9o(2).pdf. Acesso em: Io mar. 202I.

Mobbing: la persécusion au travail. Paris: du Seuil, 2012. p. 136

The mobbing encyclopaedia. Disponível em:

〈http://www.leymann.se/English/frame.html〉. Acesso em: Io mar. 202I.

MARTINS, Sérgio Pinto. Assédio Moral no Emprego. São Paulo: Atlas, 2017, p. 20-23-3139-40-II7.

MORAES, Alexandre de. Direito Constitucional. São Paulo: Atlas, 2017. p. I6

MUÇOUÇAH, Renato de Oliveira Almeida. Assédio Moral Coletivo nas relações de Trabalho. São Paulo: LTr, 2017/2018. p. 21-22-148-57-159.

NASCIMENTO, Amauri Mascaro. Iniciação ao Direito do Trabalho. São Paulo: LTr, 2017.p. 225 .

NASCIMENTO. Sônia Aparecida Mascaro. Assédio moral no ambiente do trabalho. in Revista LTr: Legislação do Trabalho e Previdência Social, São Paulo, LTr, v. 68, n.o8, agosto, p. 922-930, 2017 .

NAVARRO. Francisco González. Acoso psíquico em el trabajo: el alma, bien jurídico a protejer. Madrid: Civitas, 2019. p. 72-75-76.

ORGANIZAÇÃO INTERNACIONAL DO TABALHO. Convenção no rm. Disponível em:

〈http://www.oitbrasil.org.br/node/472〉. Acesso em: Io mar. 2021.

. Convenção no 155. Disponível em: 〈http://www.oitbrasil.org.br/node/504 >. 
Acesso em: Io mar. 2021.

PAIAS, Tânia. Portal Bullying ajuda online. 2019. Disponível em:

https://www.portalbullying.com.pt/?option=com_content $\& v i e w=\operatorname{article} \& i d=53 \&$ Itemid $=5$ 8.

>. Acesso em: Io mar. 2021.

REZENDE, Ricardo. Direito do trabalho esquematizado. Rio de Janeiro: Forense; São Paulo: MÉTODO, 2019. p. 27.

SOARES, Flaviana Rampazzo. Responsabilidade civil por dano existencial. Porto Alegre: Livraria do Advogado, 2018, p. 42.

SÜSSEKIND, Arnaldo; MARANHÃO, Délio; VIANNA, Segadas; TEIXEIRA, Lima.

Instituições de direito do trabalho. São Paulo: LTr, 2017, p. 245. 